\title{
Professor Paulo César Sentelhas Obituary
}

\section{Farshid Ghaderifar ${ }^{1}$}

Accepted: 29 September 2021 / Published online: 6 October 2021

(c) Springer Nature Switzerland AG 2021

Professor Paulo César Sentelhas, 1964-2021.

It is with deep sadness that we announce the death of Paulo César Sentelhas, Professor of Agrometeorology of Sao Paulo University in Brazil, who died in the evening of 21 September 2021, one week before turning 57. He had suffered illness with complications from COVID-19, but his passing was unexpected.

Prof. Sentelhas was born in 1964. He graduated from the University of Espirito Santo do Pinhal in 1987 and achieved his master's science in Agrometeorology from University of São Paulo in 1992. He obtained his PhD in irrigation and drainage from University of São Paulo in 1998.

He worked as research in IPMET/UNESP (1988-1994) and Agronomic Institute of Campinas (IAC) (1994-1996). Since 1996, he was professor in the Department of Biosystems Engineering in "Luiz de Queiroz" College of Agriculture, which held the position of full professor.

He was secretary of the Brazilian Society of Agrometeorology (1995-1997 and 2001-2003) and at the same institution was the president (2005-2007). Also, he was the president of the Latin-American Federation of Agrometeorology (2005-2007). From 2005 to 2013, he was the Brazilian representative of the World Meteorological Organization.

Between 2013 and 2015, he was the Scientific Editor of Scientia Agricola and since 2015, for the same journal, was the Editor-in-Chief. Moreover, he was Associated Editor of International Journal of Biometeorology (ISBM-Springer) and member of the Editorial Board in International Journal of Plant production (IJPP-Springer), Italian Journal of Agrometeorology (SIA, Italy), Applied Sciences (Springer), and AgriScientia (University of Córdoba, Argentina).

He was twelve times professor honored by the Agricultural Engineering classes, author of 224 articles, advisor to 30 masters and 28 doctors and 5 post-docs and 90 undergraduates.

He will be sorely missed by colleagues and friends. Our thoughts are with his wife, and three daughters.
Farshid Ghaderifar

farshidghaderifar@yahoo.com

1 Gorgan University of Agricultural, Sciences and Natural Resources, Gorgan, Iran 